Penulis:

Mick Mordekhai Sopacoly

Izak Y.M. Lattu

Afiliasi:

Universitas Kristen Satya

Wacana

Korespondensi:

mordekhaisopacoly913@

gmail.com

\title{
CHRISTIANITY AND ONLINE SPIRITUALITY
}

\section{Cybertheology as a Contribution to Theology in Indonesia}

\begin{abstract}
The mobilization of information, technology, and social change marked by the presence of cyberspace not only affects the way people think in building relationships with others and themselves but also the process of developing faith and spirituality. Using the methods of qualitative research, literature study, and Focus Group Discussion (FGD), this research finds that in the context of the COVID-19 pandemic, Christian religious patterns are changing drastically, driving all churches to move to virtual reality. The Christian notion of spirituality is also being transformed so that the experience with God is believed to occur not only in the physical space of the church but also in virtual reality. "Clickactivism" forms a new faith community determined by click and spiritual experiences which strength lies in the imagination of communities and individuals. This study concludes that cybertheology is an important contribution in helping Indonesian Christians to have a strong spirituality about God who cannot be confined within time and space.
\end{abstract}

Keywords: christianity, cybertheology, online, spirituality, Indonesia.

\section{KEKRISTENAN DAN SPIRITUALITAS ONLINE \\ Cybertheology sebagai Sumbangsih Berteologi di Indonesia}

SOPACOLY \& IZAK

Y.M. LATTU

DOI: $10.21460 /$ gema.

2020.52.604

This work is licenced under a Creative

Commons Attribution-

NonCommercial 4.0

International Licence. 
spiritualitasnya. Metode yang digunakan ialah penelitian kualitatif, studi literatur, dan Focus Group Discussion (FGD). Hasil penelitian menemukan bahwa dalam konteks pandemi COVID-19, pola beragama Kristen berubah secara drastis sehingga memaksa semua gereja untuk pindah ke realitas virtual. Pemahaman kekristenan tentang spiritualitas juga bertransformasi sehingga pengalaman dengan Tuhan diyakini tidak terbatas dalam ruang fisik gereja tetapi juga dalam realitas virtual. "Aktivitas klik" membentuk sebuah komunitas iman yang baru, yang ditentukan oleh klik dan pengalaman spiritual yang kekuatannya terletak pada imajinasi komunitas dan individu. Karena itu, studi ini menyimpulkan bahwa teologi cyber menjadi kontribusi penting untuk membantu kekristenan di Indonesia untuk berspiritualitas mengenai Tuhan yang tidak dapat dikurung dalam ruang dan waktu

Kata-kata kunci: kekristenan, spiritualitas, online, teologi cyber, Indonesia.

\section{PENDAHULUAN}

One of the most searched for prayers in March 2020 was "Coronavirus prayer", which are prayers that ask God for protection against the coronavirus, prayers to stay strong, and prayers to thank nurses for their efforts (Bentzen, 2020: 55).

Penelitian mengejutkan oleh Jeanet Sinding Bentzen ini menjelaskan bahwa pada bulan Maret 2020 terjadi lonjakan tertinggi dalam rekaman sejarah untuk pencarian kata "prayer" di mesin pencarian google oleh masyarakat global saat pandemi virus COVID-19. Secara online, masyarakat global meminta perlindungan dari Tuhan, tetap bertahan, dan juga syukur kepada Tuhan bagi para medis yang sedang berjuang. Hal serupa terjadi juga di Indonesia. Fachrul Razi sebagai Menteri Agama Indonesia, menuturkan bahwa orang Indonesia di tahun 2019 sering menggunakan media sosial guna mencari informasi soal keberadaan dan sifat Tuhan. Masyarakat Indonesia mempelajari agama lewat media sosial. Sebagian besar menggunakan media sosial untuk mempelajari Tuhan. Indeks tertingginya 100, orang Indonesia yang menggunakan media sosial mencari dan menyebarkan konten tentang agama yakni 9,89. Seperti keberadaan Tuhan indeks yang didapat $(43,91)$, sifat-sifat Tuhan (40,31), kuasa Tuhan (40,31), dan kisah hidup orang-orang suci $(36,72)$ (CNN Indonesia).

Berdasarkan hal-hal ini, maka dapat dipahami bahwa teknologi dan dimensi spiritual manusia mengalami integrasi karena manusia mengizinkan teknologi dan dunia online mempengaruhi relung hati manusia termasuk pandangannya mengenai realitas, struktur makna (structures of meaning) serta identitas (sense of identity) (Macalanggan, 2017: 112). Corak spiritualitas ini disebut sebagai spiritualitas online. Spiritualitas adalah proses pencarian makna terhadap yang transenden sehingga memberi inspirasi bagi seseorang untuk menjalani hidup dan memberi makna bagi lingkungan sekitarnya.

Dalam kaitannya dengan iman Kristiani, Allah menjadi keyakinan utama dalam kehidupan seseorang, yakni kehidupan yang 
saling berinteraksi merujuk pada kehidupan Yesus dan spirit Roh Kudus. Karena itu, kekristenan dan spiritualitas online merupakan keyakinan akan Allah dalam Yesus dan kuasa Roh Kudus berdasarkan pengalaman di dalam dunia online atau dalam realitas virtual (virtual reality). Dunia virtual membawa banyak perubahan dari segala aspek kehidupan yang mempengaruhi relasi antarmanusia maupun relasi manusia dengan Tuhan. Jika teologi dipahami sebagai refleksi manusia tentang Tuhan dan sesama ciptaan, maka bagaimana berteologi cyber (cybertheology) dalam dan terhadap click-sphere?

Kenyataan-kenyataan ini perlu direspon dan ditanggapi secara serius. Tantangan agama semakin besar sehingga kekristenan perlu mengambil andil juga dalam dunia online, yakni berteologi di dunia cyber (cybertheology). Akan tetapi, diskursus teologi yang mengembangkan teologi cyber dalam hubungannya dengan kekristenan dan spiritualitas online di Indonesia mengalami keterlambatan. Gereja menganggap bahwa perkembangan dan perubahan sosial (social change) sebagai ancaman bagi doktrin yang selama ini dianut selama berabad-abad bahkan paham yang sudah selesai (final). Pam Smith mengatakan banyak gereja arus utama menaruh kecurigaan, dan bahkan ketakutan untuk mengeksplorasi penggunaan komunikasi digital yang sekarang tersedia (Smith, 2016: 11). Banyak gereja mengurung Tuhan dalam dunia offline antara lain dalam dinding-dinding gereja dan pertemuan-pertemuan ritual secara ragawi yang dianggap suci. Namun, ketika berada di dunia lain (online), Tuhan tidak lagi dibawa.

Di saat terjadi pandemi global COVID-19, perdebatan teologis sangat masif di saat harus beribadah di rumah, apalagi ketika PGI (Persekutuan Gereja-gereja di Indonesia) merekomendasikan untuk melakukan ibadah online dengan memakai teknologi sebagai sarana bagi jemaat untuk mengalami Tuhan. Banyak gereja yang menolak untuk melaksanakan ibadah dan berdoa online sebab sebelum wabah ini terjadi, banyak gereja-gereja arus utama menganggap bahwa Tuhan tidak memakai media sosial atau pencipta situs Facebook bukanlah Tuhan yang "membaca" setiap doa yang tertulis secara digital. Hal tersebut dapat dilihat dalam tulisan ini yang dibatasi secara khusus pada jemaat dalam masyarakat urban yang sangat masif menggunakan teknologi namun terlihat tidak siap dalam berteologi di ruang virtual.

Akibatnya, muncul pandangan yang tersebar, antara lain: "kurang beriman", "tidak beriman", "takut menghadapi tantangan", dan lain-lain sebagainya (Widjaja et al., 2020: 128). Tak jarang ditemui juga bahwa generasi digital (digital native) bahkan juga generasi sebelumnya di Indonesia, merasa lebih dekat dengan Tuhan dengan memakai media atau live streaming. Karena itu, merespon berbagai fenomena yang terjadi di Indonesia, tulisan ini hendak membantu gereja untuk menyusun kerangkaberpikir,menanggapi, sertamenjawab perkembangan zaman dan pada akhirnya berani untuk mengembangkan teologi cyber (cybertheology) sebagai bagian dari landasan ekspresi spiritual dan representasi sehari-hari serta imajinasi terhadap yang sakral di dunia online atau realitas virtual (virtual reality).

Tulisan ini akan menjawab pertanyaanpertanyaan: (1) Mengapa imajinasi menjadi kekuatan yang penting dalam pola beragama secarakhususkekristenandalamrealitas virtual? Poin pertama menjadi penting untuk dibahas 
untuk memberi pemahaman bahwa imajinasi adalah proses memaknai yang transenden sekalipun kekristenan telah hadir dalam realitas virtual, mereka dapat memaknai-Nya. Dunia online ternyata juga mempengaruhi iman dan spiritualitas kekristenan tidak hanya dalam pertemuan fisik. (2) Bagaimana kekristenan menemukan corak spiritualitas di dunia online sehingga terdorong untuk berteologi cyber (cybertheology) dalam komunitas iman berbasis click-activism? Berdasarkan (1), poin kedua muncul ketika telah mengetahui kenyataan-kenyataan kekristenan dalam realitas virtual yang menekankan pengalaman terhadap yang transenden, yakni spiritualitas online sehingga mendorong kekristenan merumuskan teologi cyber (cybertheology). Kemudian yang (3) Bagaimana tantangantantangan berteologi cyber di Indonesia? Poin ketiga ini menekankan kontribusi penting bagi teologi Kristen di Indonesia atas dasar kenyataan dan dinamika keagamaan dalam realitas virtual sehingga pemahaman teologi cyber sangat dibutuhkan untuk teologi Kristen di Indonesia.

\section{METODE PENELITIAN}

Artikel ini menggunakan jenis penelitian deskriptif-analitis dengan menggunakan metode penelitian kualitatif untuk mengeksplorasi dan memahami temuantemuan yang diperoleh. Penekanan dalam tulisan ini terletak pada kerangka teoritik (diskusi teori) dengan menggunakan analisis sosio-teologis sehingga membantu mengkonstruksikan pemahaman kekristenan dan spiritualitas online dalam berteologi cyber di Indonesia. Dominasi pengambilan data dalam tulisan ini berasal dari studi kepustakaan (literature studies) melalui berbagai macam buku, literatur, jurnal penelitian, artikel online, atau catatan-catatan yang berkaitan dengan penulisan. Selain itu, data-data diambil dengan menggunakan metode Focus Group Discussion (FGD). Metode FGD adalah metode pengumpulan data yang dihasilkan dari eksplorasi interaksi sosial yang terjadi dalam proses diskusi. Tujuan metode ini membantu memperoleh data informasi yang kaya akan berbagai pengalaman sosial dari interaksi pada individu yang berada dalam suatu kelompok diskusi. Secara khusus, data-data dari webinar online atau diskusi virtual (daring) sehubungan dengan diskursus yang dibahas.

\section{KEKRISTENAN, IMAJINASI, DAN RE- ALITAS VIRTUAL (VIRTUAL REALITY)}

Tidak dapat dipungkiri bahwa di era yang serba canggih ini kehidupan manusia seperti amfibi, artinya manusia hidup dan beradaptasi dalam dua dunia, yakni dunia offline dan online. Pepatah kuno yang mengatakan: "mulutmu harimaumu" berubah menjadi "jarimu harimaumu", yang berarti tidak hanya mulut yang harus dijaga tetapi jari-jemari. Eksistensi manusia berubah dari "I am thinking therefore I am”, yang berarti "aku berpikir, maka aku ada", menjadi "I am clicking, therefore I am", yang dapat diartikan "aku meng-klik, maka aku ada". Teknologi menjadi bagian dari kebutuhan manusia bahkan telah terintegrasi dengannya. Kenyataan ini oleh Brian Edgar yang mengutip Donna Haraway mengatakan 
bahwa "manusia adalah cyborg" (we are all cyborgs). Secara fisik, manusia bukan bagian dari mesin, tetapi secara kultural, manusia menjadi bagian di dalamnya (Edgar, 2010: 4). Internet telah hadir dan membentuk budaya manusia dalam realitas yang dikenal sebagai realitas virtual (virtual reality).

Pada awal 1980-an, penulis fiksi ilmiah William Gibson menggunakan kata "virtual" untuk menggambarkan dunia virtual baru dalam bentuk "halusinasi konsensual" yang dialami oleh orang-orang yang tinggal atau bekerja di ruang abstrak dan dibangun oleh jaringan komputer. Secara umum, konsep ini digunakan sebagai metafora untuk ruang fisik yang tidak tersedia di jaringan komunikasi elektronik. Bräuchler menjelaskan bahwa dunia maya dapat dipahami sebagai ruang sosial yang dibentuk oleh internet, yang berarti lingkungan online di mana setiap orang yang memiliki akses internet dapat bertemu, berinteraksi, berkomunikasi, dari kelompok dan menegosiasikan identitas, berdiskusi, berbicara, bertukar informasi, dan bermain baik secara bersamaan atau dengan jeda waktu, tanpa arah, dua arah, multi-arah (Bräuchler, 2013: 14).

Internet menjadi sebuah sistem jaringan yang mengantar manusia ke dalam dunia baru yang disebut ruang cyber (cyberspace). The Oxford Online Dictionary mendefinisikan ruang cyber sebagai "lingkungan nosional tempat komunikasi melalui jaringan komputer terjadi." Kata nosional (abstrak) digunakan karena dunia maya itu sendiri tidak ada secara fisik. Ini adalah ruang metaforis yang ada dalam pikiran manusia, terutama ketika bercakap-cakap dengan orang lain seolah-olah sedang bertemu dalam ruang tertentu (Duc, 2015: 136). Bräuchler juga mengatakan:

\begin{abstract}
"Virtual to refer to the 'imaginary'which is an integral component of the 'real' human world, but can still differ qualitatively” (Bräuchler, 2013: 14).
\end{abstract}

Kehidupan di dunia maya adalah kelanjutan dengan "kehidupan nyata". Orangorang melakukan online hampir seperti apa yang mereka lakukan saat offline, tetapi mereka melakukannya secara berbeda. Ruang cyber (cyberspace) dianggap bisa melayani segala kepentingan manusia dan mengatasi segala keterbatasan manusia dengan mengembara dalam berbagai realitas tanpa batas (Wahyudin, 2011: 348). Seperti yang dijelaskan sebelumnya bahwa ruang cyber merupakan ruang metaforis dalam pikiran manusia yang sedang membayangkan bahwa seseorang sedang bertemu secara langsung tetapi dengan cara yang berbeda ternyata juga berlaku bagi tindakan manusia dalam beragama. Misalnya, ketika postingan doa-doa, ayat-ayat suci, narasi pengalaman spiritual manusia memenuhi timeline Facebook, manusia bermetaforis atau berimajinasi seolah-olah sedang bertemu dengan Yang Ilahi serta komunitas imannya sekaligus memikirkan keberimanannya dalam realitas virtual tersebut. Dalam ilmu sosial disebut dengan "theatre of mind", yakni manusia ketika membaca, dalam pikirannya sedang berimajinasi terhadap bacaan tersebut.

Inilah sebuah kenyataan kehidupan manusia yang awalnya berfokus pada human sentris, kini bertambah pada data sentris. Manusia yang tidak hanya mencari dan bertemu dengan sesamanya demi kebutuhan informasi agama atau pencerahan iman dalam pertemuan atomik, tetapi melihat dan mencari melalui data-data dalam ruang cyber. Teknologi yang memuat data-data algoritma 
virtual serta informasi yang diproduksi juga mempengaruhi identitas, yakni: imajinasi, cara berpikir, tindakan, relasi, bahkan relung hati dan spiritualitasnya. Semakin banyak manusia menghabiskan waktu di dunia online dan secara sadar maupun tidak, realitas itu telah memenuhi segala kebutuhannya termasuk agama dan identitasnya yang membentuk bagian terpenting dari struktur masyarakat (O’Leary, 2004: 37).

Berkaitan dengan hal tersebut, maka pikiran dan imajinasimanusiamenjadikekuatan penting ketika berada dalam realitas virtual. Dalam sejarah kekristenan pun ternyata sudah menuai perdebatan, yakni virtualitas ekaristi (Sheilds, 2011: 6). Pada bulan Oktober 1517, Martin Luther dengan pernyataan "Sembilan Puluh Lima Dalil" di pintu gereja Wittenberg dengan inti keberatannya adalah pada doktrin Katolik tentang keberadaan nyata Kristus dalam ekaristi. Luther menegaskan bahwa tubuh dan darah Kristus dalam perjamuan kudus hadir "di dalam, bersama, dan di bawah" roti dan anggur. Kelompok Calvin yang menganut doktrin virtualisme menolak gagasan Luther dengan menegaskan bahwa Kristus tetap hadir di dalam perjamuan kudus, namun secara spiritual, yaitu di dalam Roh Kudus, sedangkan roti dan anggur berfungsi sebagai tanda dan meterai keselamatan yang dihadirkan oleh Kristus (Adiprasetya, 2016: 88). Kenyataan-kenyataan ini membuktikan bahwa setiap hari kekristenan selalu menjadi bagian di dalamnya. Ia tidak bisa hidup tanpa berimajinasi terhadap Yang Ilahi.

Misalnya juga sebelum melantunkan pengakuan iman (credo), kekristenan selalu memulainya dengan kalimat berikut: “... dengan seluruh umat di segala tempat dan sepanjang masa... marilah kita mengucapkan pengakuan iman." Artinya, secara imajinatif tercipta perasaan menyatu tidak hanya jemaat yang hadir dalam satu gereja, tetapi seluruh dunia dari masa lampau sampai masa kini dianggap sebagai bagian dari tubuh dan darah Kristus. Hal itu juga yang dibayangkan dan dihayati ketika jemaat berdoa dengan menutup mata. Mereka merasa sedang berbicara langsung dengan Tuhan. Karena itu, manusia sejatinya terus menjalin hubungan dengan Tuhan yang adalah realitas virtual itu sendiri.

Secara sosiologis Tuhan dipahami secara imajinasi oleh manusia, di mana manusia mencari Tuhan yang tidak kelihatan namun eksistensi-Nya dapat dirasakan oleh intuisi (mata iman). Memakai istilah Byrne, Tuhan tidak hadir secara atomik (physically), melainkan secara digit (virtual) (Byrne, 2000: 2). Dalam konsep kekinian menyebutnya sebagai imajinasi-virtual (virtual imagination). Paul Pruyser melakukan percakapan kritis dengan filsuf Ludwig Feuerbach, yang mengatakan, "Imajinasi adalah organ asli agama." Bagi Feuerbach, agama adalah antropologi; bagi Pruyser, agama adalah proses ilusi, yang dipenuhi dengan misteri yang membuat orang tercengang. Ia juga memegang transendensi, yang melintasi kerangka ruangwaktu. Hal ini disebut oleh Jaco Hamman sebagai kecerdasan transisional (transitional intelligence) (Hamman, 2017: 81).

Giordano Bruno memandang imajinasi sebagai suatu daya spiritual di dalam diri manusia. Dengan kata lain, imajinasi adalah kendaraan bagi Roh Kudus. Sedangkan Immanuel Kant memasukkan imajinasi dalam sistem transendental, yaitu sebuah kondisi tersembunyi dari segala pengetahuan 
yang mendasari objektivitas objek dalam subjektivitas subjek. Imajinasi itulah yang akan memprakondisikan pengalaman manusia dengan dunia (Hudjolly, 2011: 105). Secara sosio-teologis, manusia mencari dan memperbincangkan-Nya setiap saat. Kekuatan imajinasi menjadi penting karena menghubungkan manusia dengan dunia spiritual dan tak terlihat secara kasat mata (Mujiburrahman, 2015: 5). Hal tersebut tidak muncul dengan sendirinya dalam imajinasi manusia, melainkan dari pengalamanpengalamannya.

Nuban Timo mengutip H.M. Kuitert yang mengatakan, “Apa yang manusia katakan tentang Allah (Yang Ilahi) dan hal-hal yang ada di atas tidak datang dari atas, itu selalu dari bawah." Artinya pemahaman manusia tentang Allah selalu berasal dari pengalaman manusia dalam masyarakat (Nuban Timo, 2015: 228). Seperti halnya tembok ratapan yang dianggap oleh masyarakat sebagai tembok doa. Secara sosiologis, ketika memahami "tembok" sebagai doa maka itu berangkat dari "kelompok masyarakat" yang tidak dapat dipisahkan dari pengalaman masyarakat itu. Akan tetapi, bagi orang lain, tembok ratapan hanya kumpulan batu bata dan sisa reruntuhan kerajaan di masa lalu. Di era digital ini, tembok-tembok tersebut dipahami telah berpindah ke tembok-tembok Facebook, Instagram, Twitter, YouTube, dan lain-lain. Doa-doa, ayat-ayat Alkitab, dan ibadah-ibadah online telah memenuhi timeline dan mempengaruhi imajinasi manusia terhadap Yang Ilahi. Adiprasetya, mengutip Mircea Eliade, menjelaskan bahwa bagi manusia religius, ruang perjumpaan dengan Yang Ilahi tidaklah seragam (Adiprestya, 2020: 135). Bagi orang lain, beberapa tempat memberikan pengalaman transenden yang berbeda dari satu orang ke orang lainnya, salah satunya ialah pengalaman agamanya dalam realitas virtual.

Persoalannya ialah ada pahampaham kekristenan tradisional (pre-digital) memahami bahwa Tuhan menetap di dalam ruang yang disebut "Surga" dan "waktu" yang disebut kekekalan (eternal). Kenaikan Yesus "ke Surga" merujuk pada pemahaman penulis Alkitab bahwa Tuhan "pergi ke atas" yakni ke sebuah tempat yang jauh di atas sana. Lavinia Byrne dalam tulisannya mengatakan, "Doa Bapa kami yang di Surga" hendak menunjukkan bahwa Allah berada di suatu tempat khusus (somewhere), bukan di berbagai tempat (everywhere), atau tidak berada di suatu tempat (nowhere). Konsep tradisional ini bermasalah dengan konsep sains yang memberikan gambaran mengenai "ruang" khususnya langit yang tak terbatas. Pertanyaan sumbangsih sains bagi teologi ialah: Di langit manakah letak Surga itu kalau langit sendiri tak terbatas? Tuhan dianggap "jauh di atas bintang-bintang" (beyond the stars). Hal ini tentunya membawa sebuah imajinasi mengenai adanya tempat fisik yang dipahami oleh manusia sehingga Tuhan menetap di surga sembari mengawasi dunia (Byrne, 2000: 1-2). Pemahaman mengenai eksistensi Tuhan di zaman pre-digital ini sama dengan konsep Foucault yang disebut "panopticon", yakni Tuhan seolah-olah berada di atas menara yang mengawasi para narapidana di dalam penjara.

Pada titik ini muncul teologi tentang ruang spiritual yang melampui ruang fisik tempat hidup manusia. Ruang itu adalah ruang suci dan memungkinkan kehadiran Allah di dalam dunia dan komunitas Kristen dengan cara misterius dan unik. Byrne menyebutnya 
sebagai "ruang sakramental" (sacramental space), ruang yang tak terbatas di mana Tuhan yang virtual itu juga bereksistensi dalam dunia cyber (Byrne, 2000: 2). Dalam pemahaman Derrida, hal itu berarti bahwa konsep ruang perlu mengalami dekonstruksi. Dekonstruksi berarti sebuah makna dari suatu kata yang tidak pernah definitif alias ada kemungkinankemungkinan makna lain yang muncul (Hardiman, 2015: 306). Dekonstruksi ruang yang tidak hanya berpangkal pada ruang (space), tetapi menjadi ruang (sphere). Karena itu, dapat dipahami bahwa sphere bukan sebagai ruang fisik misalnya di gedung gereja, tetapi ruang mental (yang berhubungan dengan metafora dan imajinasi) di mana manusia bisa merasakan Tuhan (hasil FGD). Persekutuan dengan Tuhan tidak hanya ditentukan oleh "ruang fisik", tetapi juga "ruang hati". Nuban Timo justru mengkalimatkan, "God does not live in church buildings but in good person's hearts" (Nuban Timo, 2018: 46). Hati yang ingin mengalami Tuhan serba hadir (omnipresence). Memang gedung kebaktian ditahbiskan sebagai rumah Allah, mimbar, atau altar, sebagai tempat pemberitaan firman dan pelayanan sakramen, tetapi perlu diingat bahwa langit pun tidak dapat memuat Allah, terlebih lagi rumah yang jemaat tahbiskan (1 Raj. 8:27) (Nuban Timo, 2018: 187). Joas Adiprasetya mengutip perkataan tahun 1529 dari Luther:

\footnotetext{
"Kristus pastilah hadir dan aktif di manamana, bahkan di dalam daun terkecil dari sebuah pohon... di dalam setiap ciptaanNya, di dalam keberadaannya yang terdalam atau yang terluar, melingkupi, menembusi, di atas, di bawah, di belakang, di depan, sehingga tak mungkin ada yang lebih hadir, tak ada yang lebih terhubung secara erat dengan setiap ciptaan kecuali Allah dan kuasa-Nya” (Adiprasetya, 2016: 91).
}

Secara spiritual, melalui dunia maya ini, manusia dapat mengalami Tuhan sebagaimana juga dalam dunia offline. Hal itu merupakan kenyataan bahwa realitas virtual telah meresapi setiap aspek kehidupan manusia. Itu berarti bahwa bentuk komunikasi ini harus tercermin tidak hanya secara sosiologis tetapi juga spiritual dan teologis (Duc, 2015: 137). Kenyataankenyataan ini berimplikasi besar bagi dunia teologi, yakni teologi cyber (cybertheology).

\section{KEKRISTENAN, SPIRITUALITAS ON- LINE, DAN TEOLOGI CYBER (CYBER- THEOLOGY)}

Berdasarkan pemahaman dan kemampuan manusia untuk mencari makna terhadap yang transenden dalam realitas virtual, maka dapat dipahami bahwa teknologi dan dimensi spiritual manusia mengalami integrasi karena manusia mengizinkan teknologi dan dunia online mempengaruhi relung hati manusia termasuk pandangannya mengenai realitas, struktur makna (structures of meaning) serta identitas (sense of identity) (Macalanggan, 2017: 112).

Sejak revolusi industri dan muncul berbagai macam teknologi baru, membuka peluang bagi manusia untuk mengembangkan imannya melalui media yang lebih modern. Penggunaan teknologi sebagai alat berkomunikasi dengan sesama manusia, dapat pula membawa manusia untuk berkomunikasi dengan Sang Pencipta. Upacara peribadatan yang mulanya dilakukan dalam ruang fisik, dapat pula muncul di ruang virtual tanpa batasan tembok-tembok (beyond the wall). Realitas virtual yang berbasis pada internet 
tidak hanya membantu manusia untuk mencari informasi, namun juga untuk berpartisipasi dalam ranah keagamaan.

Spiritualitas dan iman seseorang bergerak secara dinamis mengikuti perkembangan dan konteks kehidupannya. Iman pada masa kini sudah tidak lagi terpenjara dalam teks-teks suci, naskah kuno, papirus, batu bertulis, dan media-media atomik lainnya. Hal ini menunjukkan bahwa spiritualitas merupakan fenomena kehidupan manusia yang jauh melampaui agama secara institusional yang membatasi jemaat pada satu pengalaman spiritual (mono-experience). Meskipun antara spiritualitas dan agama merupakan dua entitas yang berbeda, namun tidak dapat dipisahkan. Pengalaman spiritual ketika Allah diyakini oleh kekristenan menjadi keyakinan utama dalam kehidupan yang saling berinteraksi merujuk pada kehidupan Yesus serta "spirit" dalam Roh Kudus. Tetapi juga spiritualitas dengan kapasitas fundamental dengan pencarian makna, nilai, dan tujuan hidup yang terbentuk ke dalam pilihan-pilihan bagaimana seseorang menjalani hidupnya, apakah ia seorang atlit, pendidik, dan sebagainya (Anamofa, 2013: 196) termasuk manusia yang mencari makna sebagai pengembara di dunia online (online pilgrimage). Itu berarti manusia memiliki multi-experience. Gary L. Thomas membuktikan sembilan corak spiritualitas, di mana setiap orang dengan cara-cara berbeda menghayati dan mencintai Tuhan (Thomas, 2009).

\section{Table Caption. Sembilan Spiritualitas Menurut Gary L. Thomas}

\begin{tabular}{|c|l|l|}
\hline No. & Macam Spiritualitas & \multicolumn{1}{c|}{ Arti } \\
\hline 1. & Tradisionalis & $\begin{array}{l}\text { Menghayati Tuhan dengan ritual, simbol, sakramen, yakni } \\
\text { dengan ikut serta dalam beribadah. }\end{array}$ \\
\hline 2. & Indra & $\begin{array}{l}\text { Menghayati Tuhan dengan indrawi, misalnya: melihat, } \\
\text { mendengar musik klasik, bahasa formal gereja, mencium } \\
\text { wangian di sekitar gereja, dan lain-lain. }\end{array}$ \\
\hline 3. & Naturalis & $\begin{array}{l}\text { Menghayati Tuhan melalui keindahan alam dan lingkungan } \\
\text { (outdoors). }\end{array}$ \\
\hline 4. & Askese & $\begin{array}{l}\text { Menghayati Tuhan dalam keheningan dan kesederhanaan } \\
\text { (listening to the quiet). }\end{array}$ \\
\hline 5. & Kontemplatif & Menghayati Tuhan sebagai pasangan mereka secara imajinasi. \\
\hline 6. & Antusias & $\begin{array}{l}\text { Menghayati Tuhan dengan misteri dan perayaan. Misalnya } \\
\text { praise and worship sembari bertepuk tangan, dan lain-lain. }\end{array}$ \\
\hline 7. & Intelektual & $\begin{array}{l}\text { Menghayati Tuhan dengan pikiran rasional, yakni: berdiskusi, } \\
\text { membaca, berdialog mengenai Tuhan. }\end{array}$ \\
\hline 8. & Pemerhati (pelawat) & $\begin{array}{l}\text { Menghayati Tuhan dengan cara menemani mereka yang sakit, } \\
\text { menderita, memperhatikan sesama dan orang asing. }\end{array}$ \\
\hline 9. & Aktivis & $\begin{array}{l}\text { Menghayati Tuhan melalui konfrontasi, yakni membela yang } \\
\text { lemah, menjadi aktivis sosial, menegakkan keadilan, dan } \\
\text { sebagainya. }\end{array}$ \\
\hline
\end{tabular}


Refleksi Thomas ini memberi pemahaman bahwa cara seseorang menghayati Tuhan bukan bersifat tunggal melainkan ada banyak cara corak spiritualitas yang bisa dikembangkan dan ditemui melalui masingmasing pengalaman. Eksistensi Tuhan tidak bisa direduksi dengan pengalaman monoexperience. Banyak misteri kehidupan yang perlu disingkapkan. Namun dalam tulisannya ini, Thomas belum menampilkan corak spiritualitas online. Era internet membuat ketertarikan pada orang-orang percaya (believer) sehingga mempengaruhi kapasitasnyabahkan imannyauntuk memahami realitas dunia dan bagaimana manusia terus hidup untuk meningkatkan potensi manusianya (Spadaro, 2014: 6). Dengan mengutip Berger, Spadaro menanyakan: Jika media elektronik dan teknologi digital mampu memodifikasi cara berkomunikasi dan bahkan cara berpikir, apa dampak bagi teologi Kristen? (Spadaro, 2014: 15). Bagi Peter Singh, teologi dalam bentuk apa pun itu, harus dan tetap berbicara mengenai relasi dengan Tuhan dan manusia sebagai subjek. Karena itu, merumuskan teologi cyber (cybertheology) menjadi kebutuhan penting untuk terus dibangun oleh kekristenan secara terus-menerus.

Cybertheology merupakan diskursus tentang ekspresi spiritual di internet dan representasi sehari-hari dan imajinasi terhadap yang sakral. Anthony Le Duc dalam artikelnya mengutip Peter Singh yang mengatakan cybertheology harus dipahami sebagai kecerdasan iman (intelligence of faith) karena mempengaruhi cara manusia berpikir, belajar, berkomunikasi, bahkan cara hidup (Duc, 2015: 140). Dalam tulisannya, Spadaro menekankan bahwa tidak cukup untuk mempertimbangkan refleksi cybertheology sebagai salah satu dari banyak kasus teologi kontekstual yang melihat secara khusus konteks manusia di mana ia diekspresikan (Spadaro, 2014: 17). Anthony Le Duc menambahkan bahwa teologi cyber perlu dibedakan dari teologi lain yang berfokus atau memberikan prioritas pada sektor atau kelompok tertentu dalam masyarakat, misalnya teologi pembebasan (kaum miskin dan kelas pekerja), teologi feminis (kesetaraan laki-laki dan perempuan), teologi perempuan (perempuan Afrika-Amerika), dan teologi Asia (perempuan dan laki-laki Asia). Namun, media sosial hari ini tidak dapat dengan mudah diisolasi sebagai kasus yang spesifik atau terisolasi dari masyarakat lainnya. Terlebih lagi, teologi cyber tidak hanya tentang merek teologi yang ditemukan di dunia maya dan harus dihilangkan dari kehidupan sehari-hari. Lingkungan digital menjadi semakin mencakup dan mempengaruhi semua aspek dan dimensi kehidupan. Karena itu, teologi cyber (cybertheology) adalah refleksi sistematis tentang dampak transformatif dari era digital pada berbagai dimensi kehidupan iman seseorang dan responsnya terhadap lingkungan yang terus berubah (Duc, 2015: 140).

Debbie Herring menjelaskan teologi cyber adalah teologi dalam (in), dari (of), dan untuk (for) "ruang cyber". Teologi dalam (in) ruang cyber berkaitan dengan materi-materi teologis yang tersedia dalam jaringan internet. Teologi dari (of) ruang cyber berisi daftar kontribusi teologis untuk studi ruang cyber. Teologi untuk (for) ruang cyber berisi tempattempat di mana manusia bisa berteologi dalam internet (Spadaro, 2014: 17). Dengan mengetik "Tuhan", "agama", "Kristus", atau "spiritualitas" di mesin pencarian google dan berbagai media lainnya maka akan tersedia 
ratusan bahkan miliaran halaman (pages). Kekristenan cenderung mengakses topik-topik seputaran agama, mengunduh (download) teks-teks dan dokumen agama, mendengarkan musik religi, khotbah, doa, kesaksian, diskusi antaragama, berdoa dan beribadah, dan lainlain sebagainya. Dalam konteks pandemi
COVID-19, penelitian terbaru oleh Bentzen menunjukkan bahwa terjadinya fenonema global di mana kata "prayer" pada bulan Maret 2020 dalam mesin pencarian google meningkat secara drastis bahkan disebutkan "level tertinggi yang pernah tercatat" (highest level ever recorded).

\section{Figure Caption. Pencarian Kata "Prayer" di Google Trend}

Figure 1: Worldwide Google searches for "prayer" during the past 4 years

(a) Jan 12016 - Apr 112020

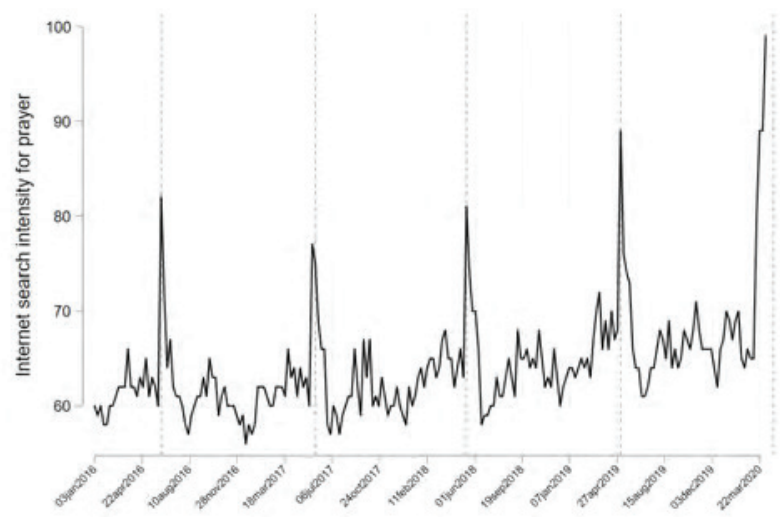

(b) Feb 1 - Apr 12020

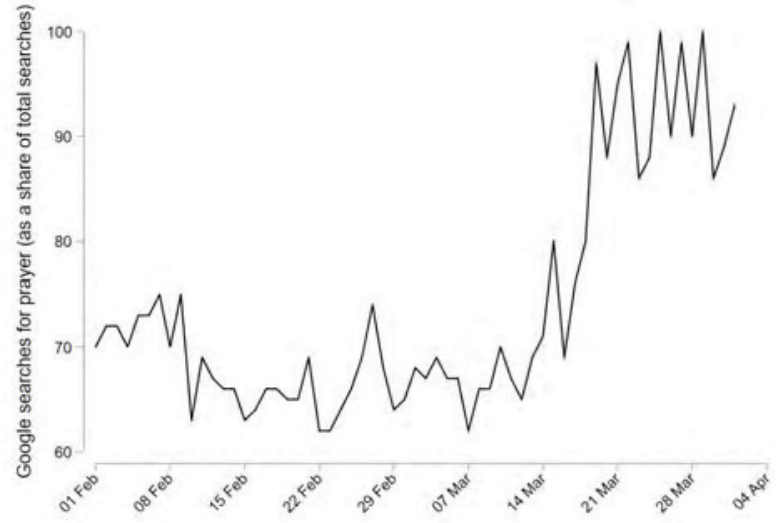

Sumber: Penelitian Jeanet Sinding Bentzen (Bentzen, 2020: 54)

Dari grafik tersebut dapat dipahami bahwa lebih dari setengah populasi dunia meminta perlindungan Tuhan dari virus, berdoa untuk tetap kuat, serta berdoa untuk para medis. Pencarian kata "prayer" ini bahkan melebihi semua kegiatan beragama seperti
Natal, Paskah, dan Ramadan. Peningkatan pesat terjadi di negara-negara yang didominasi oleh Kristen dan Islam (Bentzen, 2020: 53). Fenomena global ini bagi Glenn Young dapat digolongkan menjadi dua jenis beragama di media sosial, yakni agama online dan online 
agama (Young, 2004: 94). Agama online adalah mereka yang tertarik informasi mengenai agama, yakni: doktrin, negara, organisasi, dan kepercayaan. Sedangkan online agama ialah melibatkan aktivitas beragama misalnya beribadah secara online seperti yang dilakukan banyak gereja di saat pandemi COVID-19, berdoa, berkhotbah, meditasi, membuat video religius, dan lain-lain. Hal ini tidak berarti bahwa akan muncul agama atau aliran baru, melainkan lebih kepada tindakan spiritual dengan banyak cara, banyak jalan, dan banyak pengalaman.

Teologi cyber juga memperluas relasi. Ragawi dan fisik bisa terhambat, tetapi digital dapat terkoneksi pada aras lokal, nasional, bahkan internasional. Media sosial dan teknologi hanya akan menjadi sia-sia bila tidak terhubung satu sama lain (connected). Hal ini disebabkan karena manusia membutuhkan orang lain serta lingkungan sosialnya, baik yang dituang dalam bentuk atom maupun secara digital di dinding-dinding Facebook, Instagram, YouTube, Twitter, dan lain-lain. Misalnya, doa dengan rasa solidaritas bagi sesama yang mengalami kecelakaan, sakit kronis yang harus dioperasi, orang yang berulang tahun, lulus dari sekolah, pernikahan, bahkan korban dan penyintas COVID-19 dan sebagainya terlihat membanjiri dunia online. Ekspresi-ekspresi, seperti: pelukan, tangisan kebahagiaan, bersalam-salaman, dilakukan secara virtual sembari mengucapkan "Thanks, God". Di saat manusia beragama membaca postingan doa, secara sadar maupun tidak mereka "meng-amini" doa itu seolah-olah mereka ikut mendoakan. Hal inilah yang bagi Jennifer Cobb menyebut sebagai cyber grace. Seseorang merasa bahwa dunia online sangat terhubung dengan spiritualitasnya. Ruang anugerah yang membentuk sebuah komunitas iman yang baru, yakni komunitas suci berbasis "klik" (holy click communion). Komunitas iman yang ditentukan oleh aktivitas klik (click-activism) (hasil FGD). Komunitas online ini yang saling menghormati (mutual respect) dalam forum-forum dialog (forms of dialogue), menciptakan rasa persatuan keluarga sebagai sesama manusia (sense of unity of the human family) dan solidaritas (inspire solidarity). Komunitas online berbasis forum apologetika yang dapat ditemui ialah eksisnya sebuah grup dengan instansi agama sembari berdiskusi mengenai kekristenan yang menurut komunitas ini tidak pernah didengar oleh gerejanya sendiri (offline) (Smith, 2016: 11). Dalam beberapa kasus pun, gereja offline terkadang menyakiti jemaatnya. Tidak hanya dari para tokoh agama, tetapi juga di antara jemaat itu sendiri akibat konflik internal sembari beribadah kepada Tuhan secara kolektif (ragawi).

"Pak Pendeta, saya senang sekali ibadah
online dan saya bisa merasakan Tuhan.
Kalau ibadah offline, saya sering dibuli
karena saya jomblo" (hasil FGD).

Hal ini membuktikan bahwa lingkungan digital telah menghadirkan peluang baru untuk memperkaya pencarian seseorang akan Tuhan dan membayangkan bagaimana Tuhan dapat hadir di dunia (Duc, 2015: 142). Tuhan yang melampui simbol-simbol yang dimaknai oleh manusia bahkan mengatasi hukum-hukum gravitasi, geografi, biologi, matematika, ruang, dan waktu (Nuban Timo, 2019: 18). Dalam hal ini bangunan gereja hanya sebagai simbol dan tidak menjadi tempat satu-satunya kehadiran Tuhan. Narasi doa yang disampaikan dalam 
dinding Facebook, Instagram, YouTube, dan berbagai aplikasi tentunya Tuhan Yang Mahakuasa dapat memahaminya, seperti website yang berisi doa-doa yang tersebar di seluruh dunia bagi mereka yang terinfeksi COVID-19 dan sedang menjalani karantina, salah satunya antara lain:

\begin{abstract}
"Jesus, during Your ministry on Earth You showed Your power and caring by healing people of all ages and stations of life from physical, mental, and spiritual ailments. Be present now to people who need Your loving touch because of COVID-19. May they feel Your power of healing through the care of doctors and nurses. Take away the fear, anxiety, and feelings of isolation from people receiving treatment or under quarantine. Give them a sense of purpose in pursuing health and protecting others from exposure to the disease. Protect their families and friends and bring peace to all who love them" (Bentzen, 2020: 88).
\end{abstract}

\section{Doa ini merupakan ungkapan} yang lahir dari lubuk hati serta gerakan yang mendesak untuk mengekspresikan spiritualitas. Meminjam perkataan Nuban Timo, aktivitas doa ini menunjukkan rasa yang dalam bahkan sebuah aktivitas yang powerfull sekaligus beautiful (Nuban Timo, 2015: 3). Namun persoalan yang lain ialah hakikat doa. Kekristenan menganggap bahwa relasi manusia dengan Tuhan merupakan urusan privat karena terinspirasi dengan ayat suci yang mengatakan: "Tetapi jika engkau berdoa, masuklah ke dalam kamarmu, tutuplah pintu dan berdoalah kepada Bapamu yang ada di tempat tersembunyi. Maka Bapamu yang melihat yang tersembunyi akan membalasnya kepadamu" (Mat. 6:6). Ayat ini tidak bisa dilihat dari kacamata meaningreceive di mana manusia secara mentah menerima begitu saja ayat ini tanpa mengenali zaman penulis kitab yang tidak hidup pada abad mobilisasi masif akan informasi dan teknologi. Di zaman ini perlu adanya transformasi berpikir (meaning-making), yakni setiap orang memiliki ruang tersendiri untuk mengeksplorasi spiritualitasnya tidak hanya dalam ruang tertutup, tetapi juga dalam dunia online dan tentu saja kekuatannya ada pada imajinasi. Spadaro menyebutnya sebagai ruang pengalaman (space for experience) dan konteks eksistensial yang baru (new existential context). Internet telah menjadi tempat ketiga (third place), yakni "di antara" ruang publik (public space) dan ruang pribadi (private space), personal dan sosial. Jika demikian, maka sebetulnya dunia maya tidak sepenuhnya publik dan juga pribadi.

Hal ini dipengaruhi oleh akses konfirmasi (confirm) atau liminalitas di mana seseorang hanya mengizinkan beberapa orang yang pantas masuk dalam kehidupan digitalnya. Misalnya, mekanisme confirm itu menjadikan Facebook menjadi ruang pribadi yang berhak menentukan boleh tidaknya orang-orang berada di list pertemanan. Media Facebook telah menjadi ruang tamu dari rumah pribadi. Motivasi doa dari seseorang menjadi penting dalam kekristenan ketika hadir dalam dunia cyber kendati ada yang menampilkan diri palsu dan diri asli dalam ruang virtual (Hamman, 2017: 33) tidak hanya pada aplikasi Facebook, tetapi semua platform dan aplikasi digital. Dalam pemahaman Erving Goffman, adanya panggung muka dan panggung belakang, di mana pada panggung belakang beberapa aktor tidak menjadi seperti apa adanya dalam panggung depan (Goffman, 1959: 22). Aktor menampilkan kesuciannya dalam realitas virtual (online), tetapi dalam 
dunia fisik (offline) aktor tidak menonjolkan tindakan kesucian itu, tetapi juga sebaliknya.

Melalui dunia maya, anggota masyarakat atau jemaat yang mengalami dukacita, kata-kata simpati dan empati melalui tulisan-tulisan digital yang disertai dengan gambar dan simbol emotikon, foto, dan video kreatif berdampak secara signifikan sehingga membuat ia tidak sendiri. Dalam kasus COVID-19, meskipun tidak bisa memberikan dukungan secara atomik, tetapi masyarakat dengan berbagai cara turut memberikan doa, dukungan secara virtual baik kepada seluruh pemerintah, para medis bahkan pasien COVID-19.

\begin{abstract}
"Saya merasa di waktu sakit ini, banyak sekali yang peduli. Banyak orang dari berbagai negara tanya kabar dan 'kirim' doa. Saya senang sekali punya banyak sahabat. Orang-orang berdoa dari mana saja dan itu yang menguatkan saya. Video dan lagu yang dikirimkan kepada saya, membuat air mata jatuh sehingga setelah sembuh saya ingin menjadi lebih baik lagi” (hasil FGD).
\end{abstract}

Bambina menyebutnya sebagai "dukungan sosial secara online" (online social support) (Bambina, 2007: 6). Hal ini menunjukkan bagaimana cybertheology membantu manusia dalam berelasi dengan orang lain dan menciptakan kecerdasan relasional (relational intelligence) dalam hubungan yang otentik, penuh kasih (loving), perhatian (caring), dan hubungan etis (ethical relationship) (Hamman, 2017: 52). Karena itu, kekristenan sangat membutuhkan teologi cyber (cybertheology) ini untuk membantu menemukan kecerdasan iman dan spiritual dalam pencarian makna dan pengalaman terhadap yang transenden dan diwujudkan juga dalam menciptakan relasi yang mendalam (deep relation) dengan sesama dalam realitas virtual.

\section{TANTANGAN DAN REKOMENDASI BERTEOLOGI CYBER DI INDONESIA}

Mengutip dari Nuban Timo, kekristenan dalam berteologi cyber diajak untuk membangun bumi sebagai "prototipe surga" (Nuban Timo, 2018: 190). Melalui media sosial dan di dalam realitas virtual, kekristenan diajak untuk menjadikan dunia online sebagai ruang suci (sacred sphere). Teologi cyber (cybertheology) tidak hanya sekadar merek theology dan terpisah dengan hidup sehari-hari, melainkan menjadi kebutuhan spiritualnya terhadap Yang Ilahi. Kesadaran spiritualitas orang Kristen akan menjadikan realitas virtual sebagai wilayah jangkauan Allah yang secara imajinasi menyapa setiap nitizen melalui berbagai jenis postingan sehingga dalam aktivitas kliknya (click-activism) memberi manfaat kepada banyak orang.

Akan tetapi teologi cyber harus menyadari tantangan-tantangan di dalam realitas virtual yang terus dibanjiri dengan berbagai informasi yang tidak relevan bahkan hoax. Media menjadi mesin pembunuh massal, yakni kecenderungan produksi hoax untuk kepentingan tertentu bahkan menjadi harapan semu. Informasi digital sangat mudah untuk dimanipulasi, diedit, direkayasa, dan membuka kemungkinan untuk melakukan kebohongan publik, baik dalam hal penjiplakan maupun dalam hal pemalsuan informasi (Wahyudin, 2011: 350). Adapun ujaran kebencian (hate speech) berbasis agama menjadi 
tantangan berteologi cyber di Indonesia yang multikultural. Ceramah mengenai simbol salib orang Kristen dari seorang ustad membanjiri media sosial sehingga terjadi peperangan teologis antaragama dalam dunia virtual.

Distorsi informasi di dunia maya pada masa pandemik COVID-19 membuat masyarakat tidak mendapat informasi yang lengkap dan cenderung menjadi korban berita bohong (hoax). Belum lagi kasus deep fake yang terjadi di Amerika, yakni videovideo yang diatur oleh kecerdasan buatan (artificial intelligence), seseorang dengan mudah meniru suara orang lain bahkan bentuk muka dan rambut (CNN News). Meskipun ini belum terlalu spesifik terjadi di Indonesia, namun ketidaksiapan segala kemungkinan di masa depan akan menjadi bom waktu bila cybertheology ini tidak digarap dengan baik.

Pertarungan dan perpecahan dalam era informasi teknologi internet menjadi tantangan bagi masyarakat. Perkawinan antara perpecahan dan kurang lengkapnya informasi melahirkan sempit berpikir (homophily). Sempit berpikir menyebabkan orang hanya ingin menerima informasi dari pihak yang dianggap benar. Informasi dari pihak lain akan ditolak mentahmentah. Sempit pikir melahirkan warga masyarakat dan warga negara yang cenderung hanya melihat persamaan sebagai kekuatan berelasi. Orang yang berbeda akan terus dianggap musuh. Sempit pikir mengakibatkan orang membangun tembok-tembok sosial hanya karena salah menerima informasi. Hal ini menunjukkan bahwa teologi cyber tidak sekadar menjadi ruang ekspresi spiritual dalam postingan bahasa Kristen, tetapi juga membantu masyarakat netizen dalam menyebarkan validitas informasi yang akurat.
Tantangan lainnya ialah menumbuhkan rasa individualistis dan menghilangkan kecerdasan sosial antar sesama. Para peneliti di Jepang menemukan bahwa perkembangan sains dan teknologi berpotensi merusak hubungan-hubungan masyarakat jika tidak diiringi dengan penguatan relasi dan kecerdasan sosial masyarakat (Tempo, 2020). Berbeda dengan Barat yang bercorak individualistis, masyarakat Asia secara khusus di Indonesia hidup berkomunal (Nuban Timo, 2018: 327). Pope John Paul II mengatakan, "Electronically mediated relationship can never take the place of the direct human contact" (Duc, 2015: 148). Dalam pengertian bahwa relasi dengan orang lain yang dimediasi secara elektronik tidak akan pernah bisa menggantikan kontak langsung (fisik) manusia. Komunitas fisik memiliki kedalaman yang tidak bisa ditandingi oleh komunikasi virtual. Ruang cyber atau daring bisa eksis, namun kekristenan tidak bisa menciptakan jurang antara daring dan luring, online, dan offline.

Harari menjelaskan bahwa suatu komunitas dapat dimulai sebagai suatu pertemuan daring, tetapi agar benar-benar berkembang, komunitas tersebut juga harus berakar di dunia luring (Harari, 2018: 96). Perlu ada keseimbangan antara keduanya. Dukungan teruntuk para penyintas COVID-19 seperti yang dijelaskan sebelumnya dapat dipahami bahwa dukungan sosial berbasis daring ditambah dengan dukungan para medis berbasis luring terbukti sangat membantu untuk menemukan harapan untuk sembuh. Karena itu, di samping gereja mengembangkan dunia offline, gereja juga perlu mengembangkan cybertheology sebagai kontribusi penting bagi teologi dan spiritualitas Kristen dalam realitas virtual. 
Kenyataan yang terjadi di lapangan saat wabah COVID-19 ialah ibadah-ibadah konvensional berpindah ke realitas virtual, tetapi banyak gereja arus utama tidak siap dengan aktivitas teologi dalam dunia online. Ada gereja yang belum memadai dengan perangkat IT dan sumber daya manusia (SDM) meskipun mereka hidup dalam arus mobilisasi, teknologi, dan informasi internet di antara masyarakat urban. Adapun gereja memiliki infrastruktur yang mendukung, namun tidak tahu caranya serta minimnya sumber daya manusia. Namun, fakta beberapa gereja dari denominasi yang lain tidak begitu terkejut jika harus beribadah secara virtual karena dianggap sebelum wabah sudah terbiasa dengan ibadah virtual, infrastrukturnya memadai, dan sumber daya manusia yang tersedia dan berperan secara aktif khususnya anak-anak muda. Hal-hal ini menjadi tantangan dan harus menjadi perhatian khusus bagi gereja untuk berteologi secara dinamis dan kreatif dalam arus mobilisasi internet yang sangat masif. Karena itu, cybertheology dapat menjadi kontribusi yang sangat penting bagi kekristenan dan teologi di Indonesia.

\section{SIMPULAN}

Diskursus cyber di era yang serba virtual ini menuntut kekristenan untuk mengembangkan diskursus teologi cyber (cybertheology). Apalagi ketika wabah COVID-19 menjadi katalisator yang secara spontan memaksa kekristenan khususnya di Indonesia perlu memikirkan pengembangan spiritualitas warga jemaatnya di luar pertemuan-pertemuan fisik yang bercorak tradisionalis. Dengan sebuah kesadaran bahwa orang-orang banyak bertemu dan berinteraksi dalam dunia online. Teknologi menjadi salah satu kebutuhan dasar manusia secara khusus spiritualitasnya untuk mencari makna dan mengalami Tuhan tidak terbatas pada ruang fisik atau dinding-dinding gereja, namun juga dalam realitas virtual. Era internet membuat ketertarikan pada orang-orang percaya (believer) sehingga mempengaruhi secara imajinatif kapasitasnya bahkan imannya untuk memahami realitas dunia dan bagaimana manusia terus hidup untuk meningkatkan potensi manusianya. Karena itu, kekristenan perlu berteologi cyber (cybertheology) agar komunitas imannya memiliki kecerdasan spiritual dalam dirinya serta mampu diwujudkan dalam hubungan yang baik dan mendalam dengan orang lain dalam setiap aktivitas kliknya.

\section{DAFTAR PUSTAKA}

Adiprasetya, Joas. 2016. Labirin Kehidupan: Spiritualitas Sehari-hari bagi Peziarah Iman, Jakarta: BPK Gunung Mulia. .2020. Labirin Kehidupan 2: Berjumpa dengan Allah dalam Peziarahan Seharihari, Jakarta: BPK Gunung Mulia.

Anamofa, Jusuf Nikolas. 2013. "Meneropong Spiritualitas Ruang-Cyber dari sudut Halmahera", dalam Sefnat A. Hontong (ed.), Mata di Halmahera: Buku Peringatan HUT $V$ Universitas Halmahera Tobelo Fakultas Teologi, Yogyakarta: Kanisius, h. 193-216.

Bambina, Antonina. 2007. Online Social Support: The Interplay of Social Networks and Computer-Mediated Communication, New York: Cambira Press. 
Bentzen, Jeanet Sinding. 2020. "In Crisis, We Pray: Religiosity and the Covid-19 Pandemic", dalam Covid Economics: Vetted and Real-Time Papers, Issue 20, (20 May 2020): 52-108.

Bräuchler, Birgit. 2013. Cyberidentities at War, New York: Berghahn.

Byrne, Lavinia. 2000. "God in Cyberspace", https://ctpi.div.ed.ac.uk/wp-content/ uploads/2017/12/Byrne-2000-God-inCyberspace.pdf, Media and Theology Project Public Lectures, 2000: 1-7 (diakses 16.05.2020).

Dawson, Lorne L., and Cowan, Douglas E., (ed.). 2004. Religion Online: Finding Faith on the Internet, New York and London: Routledge.

Duc, Anthony Le. 2015. "Cyber/Digital Theology: Rethinking about Our Relationship with God and Neighbor in Digital Environment", Religion and Social Communication, Vol. 13. No. 2, December 2015: 130-158.

Edgar, Brian. 2010. "God, Persons and Machine", Christian in Science and Technology, ISCAST Online Journal 2010, h. 1-18.

Hamman, Jaco. 2017. Growing Down: Theology and Human Nature in the Virtual Age, Texas: Baylor University Press.

Harari, Yuval Noah. 2018. 21 Lessons: 21 Adab untuk Abad Ke-21, Ian Ahong (editor), Haz Algebra (alih bahasa), Manado: Global Indo.

Hardiman, F. Budi. 2015. Seni Memahami: Hermeneutik dari Schleiermacher sampai Derrida, Yogyakarta: Kanisius. Hudjolly. 2011. Imagologi: Strategi Rekayasa
Teks, Yogjakarta: AR-RUZZ.

Macalanggan, Joseph V. 2017. "Experiencing God in Cyberspace: The Role of Cybertechnology in Doing Theology", Scientia Bedista, Vol. 4, (March 2017): 109-125.

Mujiburrahman. 2015. Agama, Media dan Imajinasi, Banjarmasin: Antasari Press.

Nuban Timo, Ebenhazier I. 2018. Meng-hariini-kan Injil di Bumi Pancasila, Jakarta: BPK Gunung Mulia.

. 2019. Aku Memahami Yang Aku Imani, cetakan ke-4, Jakarta: BPK Gunung Mulia.

. 2015. Kita dan Doa-Doa Kita: Perumpamaan Kehidupan Doa Orang Percaya, Jakarta: BPK Gunung Mulia. . 2015. Polifonik Bukan Monofonik: Pengantar ke dalam Ilmu Teologi, Salatiga: Satya Wacana University Press.

Smith, Pam. 2016. "Meaningful Communities: The Growth of Virtual Churches", https://www.biblesociety.org.uk/ content/explore_the_bible/bible_in transmission/files/2016_spring/BiT_ Spring_2016_Smith.pdf(Spring 2016): 11-13 (diakses 16.05.2020).

Spadaro, Antonio. 2014. Cybertheology: Thinking Christianity In the Era of the Internet, diterjemahkan oleh Maria Way, New York: Fordham University Press.

Sheilds, Rob. 2011. Virtual: Sebuah Pengantar Komprehensif, diterjemahkan oleh Hera Oktaviani, Yogyakarta: Jalasutra.

Thomas, Gary L. 2009. Sacred Pathways: Discover Your Soul's Path to God, Grand Rapids: Zondervan. 
Wahyudin, Aep. 2011. "Spiritualitas Cyberspace: Interplay Post-SainsTeknologi dan Filosofi Spiritualitas Sains Dakwah", Jurnal Ilmu Dakwah, Vol. 5, No. 17: 347-376.

Widjaja, Fransikus Irwan, Marisi, Candra Gunawan, Togatorop, T. Mangiring Tua, dan Hartono, Handreas. 2020. "Menstimulasi Praktik Gereja Rumah di tengah Pandemi Covid-19", Kurios: Jurnal Teologi dan Pendidikan Agama Kristen, Vol. 6, No. 1: 127-139.

\section{Website}

CNN Indonesia. 2019. "Menag sebut banyak rakyat pelajari Tuhan lewat Medsos", https://www.cnnindonesia.com/ nasional/20191113170928-20-448055/ menag-sebut-banyak-rakyat-pelajarituhan-lewat-medsos (diakses 24.05. 2020).

Tempo, 2019. "Mengenai Visi Jepang Society 5.0: Integrasi Ruang Maya dan Ruang Fisik", https://tekno.tempo.co/ $\mathrm{read} / 1170120 / \mathrm{mengenal-visi-jepang-}$ society-5-0-integrasi-ruang-maya-danfisik (diakses 25.05.2020).

CNN. 2020. "What in the World: Deepfakes and Political Peril", https://edition.cnn. com/videos/tv/2020/02/03/exp-gps0202-witw-deep-fakes.cnn (diakses 25. 05.2020). 